\title{
The Role of Iron in the Pathogenesis of Porphyria Cutanea Tarda
}

\section{INHIBITION OF UROPORPHYRINOGEN DECARBOXYLASE}

\author{
J. P. Kushiner, D. P. SteinMuller, and G. R. LeE \\ From the Departments of Internal Medicine of the Veterans Administration \\ Hospital, and The University of Utah College of Medicine, \\ Salt Lake City, Utah 84132
}

\begin{abstract}
A в S T R A C T Porphyria cutanea tarda is characterized biochemically by excessive hepatic synthesis and urinary excretion of uroporphyrin I and 7-carboxyl porphyrins. This pattern of excretion suggests an impaired ability to decarboxylate uroporphyrinogen to the 4-carboxyl porphyrinogen, coproporphyrinogen, a reaction catalyzed by the enzyme uroporphyrinogen decarboxylase.

Because clinical evidence has implicated iron in the pathogenesis of porphyria cutanea tarda, these experiments were designed to study the effect of iron on uroporphyrinogen decarboxylase in porcine crude liver extracts.

Mitochondria-free crude liver extracts were preincubated with ferrous ion and aliquots were assayed for uroporphyrinogen decarboxylase activity. Uroporphyrinogens I and III, the substrates for the decarboxylase assay, were prepared enzymatically from $\left[{ }^{3} \mathrm{H}\right]$ porphobilinogen. The products of the decarboxylase reaction were identified and quantitated by three methods: ( $a$ ) extraction into ethyl acetate at $\mathrm{pH} 4.0$, back extraction into $1.5 \mathrm{~N} \mathrm{HCl}$ and spectrophotometric quantitation; (b) adsorption onto talc, esterification, paper chromatographic identification, and quantitation by liquid scintillation counting; and (c) adsorption onto talc, esterification, thin-layer chromatographic identification on silica gel, and quantitation by liquid scintillation counting. The thin-layer scintillation method proved most sensitive as it was the only method which accurately identified and quantitated the 7-carboxyl porphyrin reaction product.
\end{abstract}

Received for publication 16 December 1974 and in revised form 2 May 1975.
Uroporphyrinogens I and III were decarboxylated at the same rate by porcine hepatic uroporphyrinogen decarboxylase, and the addition of iron induced marked inhibition of the decarboxylase activity. Orthophenanthroline blocked the inhibitory effect of iron.

The inhibition of uroporphyrinogen decarboxylase by ferrous ion, coupled with its previously reported inhibitory effect on uroporphyrinogen III cosynthetase, provides a possible biochemical explanation for the pattern of urinary porphyrin excretion observed in patients with porphyria cutanea tarda and the clinical association with disordered iron metabolism.

\section{INTRODUCTION}

Porphyria cutanea tarda (PCT), ${ }^{1}$ the most common of the clinically recognized disorders of porphyrin metabolism (1), is characterized biochemically by the hepatic synthesis and urinary excretion of excessive amounts of porphyrins, particularly uroporphyrin I (URO I) and smaller amounts of 7-carboxyl porphyrin (2-4). The pattern of porphyrin excretion is similar to that found in congential erythropoietic porphyria (Günther's disease), but in PCT the erythrocyte does not appear to contribute to the excess porphyrin production.

Defects in porphyrin biosynthetic enzymes have not been clearly identified in PCT. However, the pattern of

${ }^{1}$ Abbreviations used in this paper: COPRO, coproporphyrin; COPROGEN, coproporphyrinogen; COSYN, uroporphyrinogen III cosynthetase; PBG, porphobilinogen; PCT, porphyria cutanea tarda; SYN, uroporphyrinogen I synthetase; URO, uroporphyrin; UROGEN, uroporphyrinogen; URODECARB, uroporphyrinogen decarboxylase. 


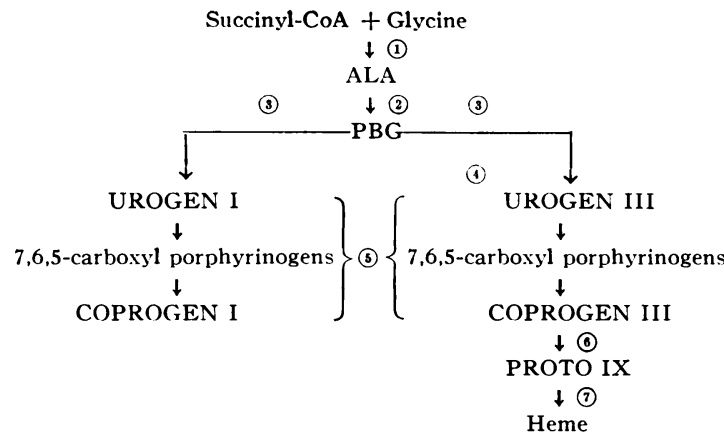

Figure 1 The enzymatic pathway for the biosynthesis of heme. (1) $=\delta$-aminolaevulinic acid synthetase; $(2)=\delta$ aminolaevulinic acid dehydratase; (3) = SYN; (4) = COSYN ; (5) = URODECARB ; $(6)=$ COPROGEN oxidase; $(7)=$ heme synthetase; $A L A=\delta$-aminolaevulinic acid; $\mathrm{PROTO}=$ protoporphyrin.

porphyrin excretion suggests the presence of more than one such defect (Fig. 1). In the normal metabolic pathway leading to the synthesis of heme, two enzymes are required for the synthesis of uroporphyrinogen III (UROGEN III) from porphobilinogen (PBG) : uroporphyrinogen I synthetase (SYN) and uroporphyrinogen III cosynthetase (COSYN) (5). The excretion of URO I in patients with PCT implies the presence of at least a partial deficiency of hepatic COSYN activity. In addition, however, the predominance of URO I and 7-carboxyl porphyrin in the urine, rather than coproporphyrin I (COPRO I), suggests the presence of a second enzymatic defect, namely decreased hepatic uroporphyrinogen decarboxylase (URODECARB) activity.

Iron overload has been implicated in the pathogenesis of PCT on the basis of clinical observations (6-9), and a previous report from our laboratory demonstrated that ferrous ion was a potent inhibitor of hepatic COSYN activity (10). The present report describes the inhibitory effect of ferrous ion on hepatic URODECARB activity.

These studies required that the reported assays for URODECARB be evaluated and a new assay developed. The decarboxylation of UROGEN has been previously assayed by the quantitation of the reaction products after extraction into organic solvents at $\mathrm{pH} 4.0$ (11, 12). However, such procedures do not extract 7-carboxyl porphyrin from unmetabolized UROGEN and thus they fail to detect this major reaction product. A new method for the assay of hepatic URODECARB activity was developed based on the utilization of a radioactive substrate and thin-layer chromatographic identification and quantitation of the reaction products.

\section{METHODS}

Normal liver was obtained from eight exsanguinated swine. Fresh or frozen liver was homogenized in 5 vol of $0.25 \mathrm{M}$ sucrose in $0.1 \mathrm{M}$ Tris- $\mathrm{HCl}$ buffer, $\mathrm{pH}$ 6.8. A fresh homoge- nate was prepared for each experiment. The homogenate was centrifuged at $37,000 \mathrm{~g}$ for $30 \mathrm{~min}$ at $4^{\circ} \mathrm{C}$. This procedure yielded a mitochondria-free solution which will be referred to as a "crude liver extract." Protein determinations were performed by the method of Lowry, Rosebrough, Farr, and Randall (13). Crude liver extracts were incubated in $25-\mathrm{ml}$ Erlenmeyer flasks for $2 \mathrm{~h}$ at $37^{\circ} \mathrm{C}$ under an air atmosphere in a Dubnoff shaker. Control flasks contained $4.0 \mathrm{ml}$ of crude liver extract, cysteine $(6.7 \mathrm{mM})$, and sufficient $0.1 \mathrm{M}$ Tris- $\mathrm{HCl}$ buffer, $\mathrm{pH} 6.8$, to make a final volume of $8.0 \mathrm{ml}$. Experimental flasks contained, in addition, ferrous ammonium sulfate $(0.7 \mathrm{mM} \mathrm{Fe})$. 0.1-0.4$\mathrm{ml}$ aliquots of the preincubation mixtures were then utilized as the source of URODECARB in the assay system.

URODECARB was assayed by a modification of the method of Romeo and Levin (11). Unlabeled and tritiumlabeled UROGEN I and III for use as substrates were prepared enzymatically from PBG. SYN was partially purified from mouse spleen (14) and COSYN was extracted from the same tissue (15). Tritium-labeled PBG was prepared enzymatically from $\left[3,5-{ }^{3} \mathrm{H}\right]$ aminolaevulinic acid (New England Nuclear, Boston, Mass.) by Dr. Ephraim Y. Levin. Dr. Levin also kindly supplied the SYN and the COSYN. PBG and cysteine were freshly prepared just before use by dissolving them in $0.1 \mathrm{M}$ Tris- $\mathrm{HCl}$ at $\mathrm{pH}$ 7.65 for UROGEN I generation or at $\mathrm{pH} 7.9$ for UROGEN III generation, to optimize COSYN activity. ${ }^{2}$

Aliquots of the incubation mixtures were then added to the tubes in which the UROGEN substrates had been generated and the volume in each tube was adjusted to $1.0 \mathrm{ml}$ with $0.1 \mathrm{M}$ Tris- $\mathrm{HCl}, \mathrm{pH}$ 6.8. The assay tubes were then incubated for $30 \mathrm{~min}$ at $37^{\circ} \mathrm{C}$ in the dark. The reactions were then stopped in one of two ways, depending upon the method to be used in determining the products of the reactions.

When reaction products were to be determined by a solvent extraction method, the reactions were stopped with $8 \mathrm{ml}$ of $2 \mathrm{M}$ acetate buffer, $\mathrm{pH} 4.4$ and the tubes were allowed to stand in the light for $30 \mathrm{~min}$ to oxidize porphyrinogens to porphyrins (16). From the clear supernate obtained by centrifuging at $37,000 \mathrm{~g}$ for $15 \mathrm{~min}$, decarboxylated porphyrins were extracted into $8 \mathrm{ml}$ of ethyl acetate. A 5-ml aliquot of this extract was back extracted into $5 \mathrm{ml}$ of $1.5 \mathrm{~N} \mathrm{HCl}$. Porphyrin concentration was measured spectrophotometrically by scanning the spectrum from 370 to $440 \mathrm{~nm}$ with a model 16 Cary spectrophotometer (Cary Instruments, Fairfield, N. J.) and applying the correction factors of With (17).

When reaction products were to be identified chromatographically, the reactions were stopped by adding $1 \mathrm{ml}$ concentrated $\mathrm{HCl}$, the porphyrinogens were oxidized in light, and the total porphyrins were quantitated spectrophotometrically on the clear supernatant solution harvested after centrifugation. Next, the $\mathrm{pH}$ of the supernatant solution was adjusted to 3.1 with solid sodium acetate, and the porphyrins were adsorbed on talc and esterified overnight in $\mathrm{H}_{2} \mathrm{SO}_{4}$-methanol (18). The porphyrin methyl esters were transferred to chloroform and identified chromatographically either on Whatman no. 1 paper by the method of Cornford and Benson (19) or on silica gel thin-layer cards (DC-Karten SI, Riedel-DeHaen AG, Hanover, Germany) developed with the benzene-ethyl acetate-methanol system of Doss (20). The fluorescent spots on the developed paper chromatograms were eluted with chloroform and the radioactivity determined in Permaflour (Packard Instrument

${ }^{2}$ Levin, E. Y. Personal communication. 
Co., Inc., Downers Grove, IIl.) in a liquid scintillation counter. In the thin-layer system, the silica gel at the fluorescent spots was scraped into Permaflour and the radioactivity determined. For chromatographic markers the methyl ester of URO I was prepared from the urine of porphyric cows and the ester of URO III was prepared from the feathers of Turacos Hartlaub (21). Methyl esters of COPRO I and III were obtained from Calbiochem (San Diego, Calif.).

\section{RESULTS}

Romeo and Levin have defined $1 \mathrm{U}$ of URODECARB activity as the amount needed to catalyze the formation of $1 \mathrm{nmol}$ of coproporphyrinogen (COPROGEN)/ml per $h$ at $37^{\circ} \mathrm{C}(11)$. In the the studies described below, decarboxylated intermediates containing 7, 6, and 5-carboxyl porphyrins were detected as products of the enzymatic reaction. In the present study, $1 \mathrm{U}$ of URODECARB activity is defined as the amount needed to catalyze the formation of $1 \mathrm{nmol}$ of 7,6, 5, and 4-carboxyl porphyrinogens $/ \mathrm{ml}$ per $\mathrm{h}$ at $37^{\circ} \mathrm{C}$.

Solvent extraction method. Unlabeled UROGEN I was utilized as the substrate and normal porcine crude liver extracts served as the source of URODECARB. The effect of iron on URODECARB activity was studied by incubating crude liver extracts with cysteine (6.7 $\mathrm{mM}$ ) and ferrous ammonium sulfate. The concentration of iron in the crude liver incubations was 0.7 mM. 0.1- and 0.4-ml aliquots were then used as the source of URODECARB. The iron concentration in the final assay tubes (final total volume, $1.0 \mathrm{ml}$ ) thus ranged from 0.07 to $0.28 \mathrm{mM}$. Neither cysteine alone nor ferrous ammonium sulfate alone had any effect on URODECARB activity. However, the combination of the two significantly inhibited activity.

In a previous report in which porphyrin synthesis in mitochoncria-free crude liver extracts was studied, it was noted that the synthesis of COPRO was gradually inhibited by increasing concentrations of ferrous ion (10). Maximal inhibition occurred at iron concentrations of $0.08-0.3 \mathrm{mM}$. Thus the iron concentrations utilized in the studies reported below were chosen to fall approximately within this range.

Seven experiments were done with aliquots of porcine crude liver extracts preincubated with cysteine alone or with iron and cysteine. The mean specific activity of URODECARB in the control extracts was $0.23 \mathrm{U} / \mathrm{mg}$ protein (range 0.18-0.28) (Table $\mathrm{I}$ ). This is quite close to the value of $0.3 \mathrm{U} / \mathrm{mg}$ protein reported by Romeo and Levin (11) in mouse liver extracts determined by the same method.

In the extracts preincubated with iron, the mean activity of URODECARB was $0.13 \mathrm{U} / \mathrm{mg}$ protein (range $0.10-0.16$ ) (Table $\mathrm{I}$ ). This represents a $44 \%$ inhibition of URODECARB activity when compared to the mean control value of $0.23 \mathrm{U} / \mathrm{mg}$ protein.
TABLE I

The Inhibitory Effect of Ferrous Ion* on URODECARB as Assayed by the Solvent Extraction Method

\begin{tabular}{cccc}
\hline \multirow{2}{*}{ Experiment } & \multicolumn{2}{l}{ URODECARB activity } & $\begin{array}{c}\text { Inhibition } \\
\text { by Fe }\end{array}$ \\
\cline { 2 - 4 } & $\mathrm{No} \mathrm{Fe}^{++}$ & With Fe $^{++}$ & \multicolumn{2}{c}{ U/mg protein } & $\%$ \\
1 & 0.24 & 0.16 & 33 \\
2 & 0.28 & 0.11 & 61 \\
3 & 0.27 & 0.13 & 52 \\
4 & 0.22 & 0.10 & 55 \\
5 & 0.18 & 0.10 & 44 \\
6 & 0.21 & 0.16 & 24 \\
7 & 0.22 & 0.13 & 41 \\
Mean & 0.23 & 0.13 & 44 \\
\hline
\end{tabular}

* With cysteine $(6.7 \mathrm{mM})$.

If all the reaction products had been extracted into ethyl acetate, the aqueous phase of the solvent extraction system should have contained predominantly URO. To check the validity of this presumption, the porphyrins in the aqueous phase were adsorbed on talc, esterified with methanol- $\mathrm{H}_{2} \mathrm{SO}_{4}$, and the methyl esters were then chromatographed on thin-layer cards. Distinct bands of 7-carboxyl porphyrin were always identified and in several experiments traces of 6-carboxyl porphyrin were also noted. Thus, not all the decarboxylated reaction products were extracted by the solvent method and the activity of URODECARB as determined by this method is falsely low. To more accurately identify and quantitate the reaction products, a paper chromatography method was evaluated.

Paper chromatography-liquid scintillation method. In these experiments, $\left[{ }^{3} \mathrm{H}\right] \mathrm{UROGEN}$ I was utilized as the substrate and the reaction products were quantitated spectrophotometrically in $\mathrm{HCl}$, esterified, and chromatographed on paper (19). The radioactivity of the fluorescent spots was determined and the amount of decarboxylated product formed was calculated. Porcine crude liver extracts were prepared as above. In 15 experiments done by this method, the mean URODECARB specific activity in control crude liver extracts was $0.39 \mathrm{U} / \mathrm{mg}$ protein (range 0.20-0.89) (Table II). In the aliquots preincubated with iron and cysteine, the mean URODECARB activity was $0.22 \mathrm{U} / \mathrm{mg}$ protein (range 0.09-0.49) (Table II). This represents a $41 \%$ inhibition of URODECARB activity when compared to the control value of $0.39 \mathrm{U} / \mathrm{mg}$ protein. Thus the inhibitory effect of iron noted with the solvent extraction method was corroborated.

The higher specific URODECARB activity obtained by the paper chromatography method is due, in part, to the elimination of small losses inherent in the sol- 
TABLE II

The Inhibitory Effect of Ferrous Ion* on URODECARB as Assayed by the Paper ChromatographyLiquid Scintillation Method

\begin{tabular}{|c|c|c|c|}
\hline \multirow[b]{2}{*}{ Experiment } & \multicolumn{2}{|c|}{ URODECARB activity } & \multirow{2}{*}{$\begin{array}{c}\text { Inhibition } \\
\text { by } \mathrm{Fe}^{++}\end{array}$} \\
\hline & No $\mathrm{Fe}^{++}$ & With $\mathrm{Fe}^{++}$ & \\
\hline & \multicolumn{2}{|c|}{$U / m g$ protein } & $\%$ \\
\hline 1 & 0.26 & 0.23 & 12 \\
\hline 2 & 0.30 & 0.23 & 23 \\
\hline 3 & 0.34 & 0.16 & 53 \\
\hline 4 & 0.49 & 0.16 & 67 \\
\hline 5 & 0.20 & 0.13 & 35 \\
\hline 6 & 0.38 & 0.09 & 32 \\
\hline 7 & 0.20 & 0.16 & 47 \\
\hline 8 & 0.32 & 0.20 & 38 \\
\hline 9 & 0.37 & 0.20 & 46 \\
\hline 10 & 0.34 & 0.19 & 44 \\
\hline 11 & 0.21 & 0.18 & 42 \\
\hline 12 & 0.35 & 0.19 & 46 \\
\hline 13 & 0.89 & 0.41 & 54 \\
\hline 14 & 0.61 & 0.49 & 20 \\
\hline 15 & 0.48 & 0.23 & 52 \\
\hline Mean & 0.39 & 0.22 & 41 \\
\hline
\end{tabular}

* With cysteine $(6.7 \mathrm{mM})$.

vent extraction- $\mathrm{HCl}$ back-extraction method. In addition, 7-carboxyl porphyrin is partially separated from URO by this method. However, of more importance is the fact that the paper chromatography method also failed to detect all the 7-carboxyl porphyrin formed. This was demonstrated by eluting the spot on the paper that was presumably pure URO I and rechromatographing the eluate on thin-layer cards. Distinct bands of 7-carboxyl porphyrin were always seen. A thinlayer method of identifying and quantitating the reaction products was then elevated.

Thin-layer-liquid scintillation method. In these experiments, both $\left[{ }^{3} \mathrm{H}\right]$ UROGEN I and $\left[{ }^{3} \mathrm{H}\right]$ UROGEN III were utilized as substrates. Porcine crude liver extracts were prepared as above. The reaction products were quantitated spectrophotometrically, esterified, and chromatographed on thin-layer cards by the method of Doss (20).

In seven experiments utilizing $\left[{ }^{3} \mathrm{H}\right]$ UROGEN $\mathrm{I}$ as the substrate, the mean specific activity of URODECARB in the control aliquots was $0.77 \mathrm{U} / \mathrm{mg}$ protein (range 0.55-0.93) (Table III). The mean specific activity of URODECARB in the aliquots preincubated with iron was $0.46 \mathrm{U} / \mathrm{mg}$ protein (range 0.31-0.56) (Table III). This represents a $40 \%$ inhibition of URODECARB when compared to the controls.

In five experiments utilizing $\left[{ }^{3} \mathrm{H}\right]$ UROGEN III as the substrate the mean specific activity of URODE-
CARB in the control aliquots was $0.79 \mathrm{U} / \mathrm{mg}$ protein (range 0.70-0.88) (Table III). Thus, nearly identical mean values for URODECARB activity were found with either the I or III isomer of UROGEN as substrate. This observation is in agreement with the results of Romeo and Levin (11). The mean specific activity of URODECARB in the aliquots preincubated with iron was $0.60 \mathrm{U} / \mathrm{mg}$ protein (range 0.46 0.66) (Table III). This represents a $24 \%$ inhibition of URODECARB when compared to the controls.

The inhibition of URODECARB by iron was demonstrated by all three assay methods, but the thin-layer method gave the highest specific activity of URODECARB. This is mainly due to the clear separation of 7 -carboxyl reaction products from unmetabolized UROGEN. Approximately $30-50 \%$ of the decarboxylated reactions products in the control studies were identified as 7-carboxyl porphyrin. In the experiments utilizing crude liver extracts preincubated with iron, 7 -carboxyl porphyrin was the major reaction product identified.

The method of expressing URODECARB activity in this report permits easy comparison with values previously reported by others $(11,12)$. However, the thin-layer-liquid scintillation method reveals porphyrins in the reaction products containing 7, 6, 5, and 4-COOH groups. Thus the enzymatic reaction involves a mix-

TABLE III

The Inhibitory Effect of Ferrous Ion* on URODECARB as Assayed by the Thin-Layer-Liquid Scintillation Method

\begin{tabular}{|c|c|c|c|}
\hline \multirow[b]{2}{*}{ Experiment } & \multicolumn{2}{|c|}{ URODECARB activity } & \multirow{2}{*}{$\begin{array}{c}\text { Inhibition } \\
\text { by } \mathrm{Fe}^{++}\end{array}$} \\
\hline & No $\mathrm{Fe}^{++}$ & With $\mathrm{Fe}^{++}$ & \\
\hline & \multicolumn{2}{|c|}{$U / m g$ protein } & $\%$ \\
\hline \multicolumn{4}{|c|}{ UROGEN I substrate } \\
\hline 1 & 0.81 & 0.31 & 62 \\
\hline 2 & 0.80 & 0.56 & 30 \\
\hline 3 & 0.93 & 0.47 & 49 \\
\hline 4 & 0.55 & 0.31 & 44 \\
\hline 5 & 0.81 & 0.56 & 31 \\
\hline 6 & 0.80 & 0.47 & 41 \\
\hline 7 & 0.71 & 0.53 & 25 \\
\hline Mean & 0.77 & 0.46 & 40 \\
\hline \multicolumn{4}{|c|}{ UROGEN III substrate } \\
\hline 8 & 0.70 & 0.60 & 14 \\
\hline 9 & 0.88 & 0.66 & 25 \\
\hline 10 & 0.73 & 0.62 & 15 \\
\hline 11 & 0.78 & 0.65 & 17 \\
\hline 12 & 0.87 & 0.46 & 47 \\
\hline Mean & 0.79 & 0.60 & 24 \\
\hline
\end{tabular}

* With cysteine $(6.7 \mathrm{mM})$. 
ture of 1, 2, 3, and 4-decarboxylations. Enzymatic activity could be expressed as nanomoles $\mathrm{COOH}$ removed per milligram protein per hour. The results of a typical experiment (12, Table III) are expressed in this fashion in Table IV. The inhibitory effect of iron is accentuated (71 vs. $47 \%$ ) when the results are expressed in this way.

To determine whether the effect of the iron compound and cysteine depended upon the formation of ferrous ion, use was made of 1,10 -phenanthroline, three molecules of which form a stable chelate with one molecule of ferrous ion (22). The iron concentration in the preincubation mixtures was $0.7 \mathrm{mM}$. Thus, if ferrous ion was responsible for the inhibition of URODECARB, then the addition of 1,10-phenanthroline in concentration less than $2.1 \mathrm{mM}$ would be expected to partially block the inhibition of URODECARB and concentrations greater than $2.1 \mathrm{mM}$ would be expected to obliterate the inhibitory effect of iron. This is what was observed and the results of a typical experiment are presented in Table $\mathrm{V}$.

\section{DISCUSSION}

The addition of iron to mitochondria-free crude extracts of normal porcine liver, significantly inhibited URODECARB.

The enzymatic conversion of UROGEN to COPROGEN, catalyzed by URODECARB, is accomplished by the sequential decarboxylation of the four acetic acid side chains (5). A single enzyme is thought to be re-

TABLE IV

The Inhibitory Effect of Ferrous Ion* on URODECARB

\begin{tabular}{ccc}
\hline Porphyrin & $\begin{array}{c}\text { nmol of } \\
\text { Reaction } \\
\text { product }\end{array}$ & $\begin{array}{c}\text { nmol coOH } \\
\text { removed/mg } \\
\text { protein/h }\end{array}$ \\
\hline $\begin{array}{c}\text { No Fe }{ }^{++} \\
\text {7-COOH }\end{array}$ & 2.12 & 0.48 \\
6-COOH & 0.55 & 0.25 \\
5-COOH & 0.96 & 0.65 \\
4-COOH & 0.24 & 0.22 \\
Total & $\overline{3.87}$ & 0.60 \\
With Fe+ & & \\
7-COOH & 2.02 & 0.46 \\
6-COOH & 0.00 & 0.00 \\
5-COOH & 0.00 & 0.00 \\
4-COOH & 0.00 & 0.00 \\
Total & 2.02 & 0.46 \\
\hline
\end{tabular}

Enzyme activity expressed as nanomoles $\mathrm{COOH}$ removed per milligram protein per hour.

* With cysteine $(6.7 \mathrm{mM})$.
TABLE V

Inhibition of the Ferrous Ion* Effect on URODECARB $\ddagger$ Thin-layer-Liquid Scintillation Method

\begin{tabular}{lc}
\hline \multicolumn{1}{c}{ Additives } & URODECARB \\
\hline & $U /$ mg protein \\
None & 0.71 \\
$\mathrm{Fe}^{++}(0.7 \mathrm{mM})$ & 0.51 \\
$\mathrm{Fe}^{++}(0.7 \mathrm{mM})+1,10$-phenanthroline $(1.5 \mathrm{mM})$ & 0.62 \\
$\mathrm{Fe}^{++}(0.7 \mathrm{mM})+1,10$-phenanthroline $(3.0 \mathrm{mM})$ & 0.72 \\
\hline
\end{tabular}

* With cysteine $(6.7 \mathrm{mM})$.

‡ UROGEN I substrate.

sponsible for the removal of all of the carboxyl groups, although the first decarboxylation proceeds more readily than the subsequent three (5). The findings reported herein, utilizing a thin-layer system of reaction product identification, demonstrate that 7-carboxyl porphyrin is an important reaction product under the conditions of our assay system. This finding is at variance with that of Romeo and Levin (11) and was demonstrable because of the superior resolution of the thin-layer system of Doss (20) in separating 7-carboxyl porphyrin from URO. The specific activity of URODECARB determined by the thin-layer system is higher than that determined by the solvent extraction technique or a paper chromatographic technique because of the ability of the thin-layer system to identify the 7-carboxyl reaction product.

When URODECARB is inhibited by iron, two effects are observed. First, there is a decrease in the number of nanomoles of reaction products formed and second, 7-carboxyl porphyrin accumulates as the major reaction product. This finding, although not incompatible with the concept that a single enzyme is responsible for the removal of all the acetic acid side-chain carboxyl groups, raises the possibility that more than one enzyme is involved in this reaction. Iron appears to exert its greatest effect upon the removal of the second carboxyl group leading to the disproportionate accumulation of the 7-carboxyl porphyrin reaction product.

The inhibitory effects of iron appear to be dependent upon the conversion of iron to, or the maintenance of iron in, the ferrous form. The iron effect was not observed unless the reducing agent cysteine was added to prevent the rapid auto-oxidation of ferrous ion that would be expected under the conditions of these experiments. In addition, the effects of iron could be blocked by the addition of 1,10-phenanthroline (Table V), a ferrous chelator of high specificity (22).

URODECARB has been reported to catalyze the decarboxylation of UROGEN III at a faster rate than UROGEN I $(12,23)$. However, Romeo and Levin found that URODECARB extracted from mouse spleen decarboxylates both isomers at the same rate (11). 
Our findings, utilizing a porcine liver enzyme system, confirm the findings of Romeo and Levin (11). The activity of URODECARB was identical for either the I or the III isomer substrate (Table III) and iron inhibited the decarboxylation of both. These studies were done utilizing either I or III isomer substrates and not mixtures of the two. Thus it remains possible that UROGEN III may be an effective competitive inhibitor for the decarboxylation of UROGEN I in vivo.

The inhibition of URODECARB by iron provides a partial explanation for the disturbance of porphyrin synthesis observed in PCT. This illness is characterized by the excessive production and excretion of predominantly 8-carboxyl (URO) porphyrin and 7-carboxyl porphyrin (2-4). Decreased activity of URODECARB is suggested by this pattern of porphyrin excretion. However the predominance of the I series isomer of URO in PCT suggests that COSYN activity might also be impaired (Fig. 1). Iron has been shown to inhibit COSYN directly (10). An additional mechanism by which COSYN might be inhibited in PCT has been described by Levin (15). Since URO III and UROGEN III are potent inhibitors of COSYN, the accumulation of these compounds resulting from impaired activity of URODECARB could lead to the synthesis of URO $I$ and its accumulation.

Any consideration of the role of iron in the pathogenesis of PCT must take into account the observation that iron overload alone does not induce PCT. In vivo studies in rats have shown that hepatic siderosis induced by the oral or intraperitoneal administration of iron leads to the urinary excretion of URO, which is normally absent from rat urine, but neither the total amount of excreted porphyrin nor the hepatic porphyrin content is increased (24). However, iron will greatly enhance the porphyrinogenic effects of hexachlorobenzene in the rat, a disease model with many similarities to PCT (25). Hexachlorobenzene and iron when fed to rats, have resulted in inhibition of hepatic URODECARB (25).

The absence of PCT in most patients with heavy iron overload, either primary or secondary hemochromatosis, casts further doubt on the concept that iron alone might be responsible for the pathogenesis of the disease. The iron stores in patients with PCT are usually increased to only two or three times normal levels, and, in some patients, they appear to be normal (8). This suggests that an underlying biochemical defect exists in patients with PCT which results in unusual sensitivity to the effects of iron and perhaps other toxic agents, such as alcohol. A genetic factor in PCT has been suggested (26). It seems reasonable to propose that PCT occurs in patients with a genetically determined abnormality in URODECARB activity. The disease might remain latent until excessive hepatic iron stores accumulate and removal of iron would produce clinical remissions.

\section{ACKNOWLEDGMENTS}

The authors are indebted to Dr. Ephraim Y. Levin who kindly supplied both reagents and advice essential to the success of the URODECARB assay. The technical advice of Dr. Manfred Doss is acknowledged with appreciation.

This investigation was supported by a Veterans Administration Research and Education Award, and by a Research grant (AM 04489) from the National Institute of Arthritis and Metabolic Diseases, The National Institutes of Health, Bethesda, Md.

\section{REFERENCES}

1. Dean, G. 1963. The prevalence of the porphyrias. S. Afr. J. Lab. Clin. Med. 9 : 145-151.

2. Nacht, S., L. C. San Martín De Viale, and M. Grinstein. 1970. Human porphyria cutanea tarda. Isociation and properties of the urinary porphyrins. Clin. Chim. Acta. 27: 445-452.

3. Dowdle, E., P. Goldswain, N. Spong, and L. Eales. 1970. The pattern of porphyrin isomer accumulation and excretion in symptomatic porphyria. Clin. Sci. (Oxf.). 39: 147-158.

4. Doss, M., W. Meinhof, D. Look, H. Henning, P. Nawrocki, W. Dölle, G. Strohmeyer, and L. Filippini. 1971. Porphyrins in liver and urine in acute intermittent and chronic hepatic porphyrias. S. Afr. Med.J. 45: $50-54$.

5. Burnham, B. F. 1969. Metabolism of porphyrins and corrinoids. 3. Biosynthesis of uropophyrinogen III. In Metabolic Pathways. Amino Acids and Tetrapyrroles. D. M. Greenberg, editor. Academic Press, Inc., New York. 3 : 429-435.

6. Lamont, N. M., M. Hathorn, and S. M. Joubert. 1961. Porphyria in the African. A study of 100 cases. Q. J. Med. 30: 373-392 + plate 3639 .

7. Lundvall, O., A. Weinfeld, and P. Lundin. 1970. Iron storage in porphyria cutanea tarda. Acta Med. Scand. $188: 37-53$.

8. Turnbull, A., H. Baker, B. Vernon-Roberts, and I. A. Magnus. 1973. Iron metabolism in porphyria cutanea tarda and in erythropoietic protoporphyria. $Q . J$. Med. 42: $341-355$

9. Uys, C. J., and L. E. Eales. 1963. The histopathology of the liver in acquired (symptomatic) porphyria. $S$. Afr. J. Lab. Clin. Med. 9: 190-197.

10. Kushner, J. P., G. R. Lee, and S. Nacht. 1972. The role of iron in the pathogenesis of porphyra cutanea tarda. An in vitro model. J. Clin. Invest. 51: 30443051.

11. Romeo, G., and E. Y. Levin. 1971. Uroporphyrinogen decarboxylase from mouse spleen. Biochim. Biophys. Acta. 230: 330-341.

12. Mauzerall, D., and S. Granick. 1958. Porphyrin biosynthesis in erythrocytes. III. Uroporphyrinogen and its decarboxylase. J. Biol. Chem. 232: 1141-1162.

13. Lowry, O. H., N. J. Rosebrough, A. L. Farr, and R. J. Randall. 1951. Protein measurement with the Folin phenol reagent. J. Biol. Chem. 193: 265-275.

14. Levin, E. Y., and D. L. Coleman. 1967. The enzymatic conversion of porphobilinogen to uroporphyrinogen catalyzed by extracts of hematopoietic mouse spleen. J. Biol. Chem. 242: 4248-4253. 
15. Levin, E. Y. 1971. Enzymatic properties of uroporphyrinogen III cosynthetase. Biochemistry. 10: 4669-4675.

16. Sancovich, H. A., A. M. C. Batlle, and M. Grinstein. 1969. Porphyrin biosynthesis. IV. Separation and purification of porphobilinogen deaminase and uroporphyrinogen isomerase from cow liver. Porphobilinogenase an allosteric enzyme. Biochim. Biophys. Acta. 191: 130-143.

17. With, T. K. 1955. Porphyrin concentrations from ultraviolet extinction. A note on the calculation. Scand J. Clin. Lab. Invest. 7 : 193-194.

18. Falk, J. E. 1964. Porpyrins and Metalloporphyrins; Their General, Physical and Coordination Chemistry, and Laboratory Methods. Elsevier Publishing Co., Amsterdam. 266 pp.

19. Cornford, P. A. D., and A. Benson. 1963. A qualitative and quantitative study of the separation of uroporphyrin octamethyl esters I and III by dioxan chromatography. J. Chromatogr. 10 : 141-157.

20. Doss, M. 1970. Analytical and preparative thin-layer chromatography of porphyrin methyl esters. Z. Klin. Chem. Klin. Biochem. 8: 197-207.
21. San Martin De Viale, L. C., A. A. Viale, S. Nacht, and M. Grinstein. 1970. Experimental porphyria induced in rats by hexachlorobenzene. A study of the porphyrins excreted in urine. Clin. Chim. Acta. 28: 13-23.

22. Smith, G. R., and F. P. Richter. 1944. Phenanthrolinc and substituted phenanthroline indicators. The G. Frederick Smith Chemical Company, Columbus, Ohio.

23. Cornford, P. 1964. Transformation of porphobilinogen into porphyrins by preparations from human erythrocytes. Biochem. J. $91:$ 64-73.

24. Shanley, B. C., S. S. Zail, and S. M. Joubert. 1970. Porphyrin metabolism in experimental hepatic siderosis in the rat. Br. J. Haematol. 18: 79-87.

25. Taljaard, J. J. F., B. C. Shanley, W. M. Deppe, and S. M. Joubert. 1972. Porphyrin metabolism in experimental hepatic siderosis in the rat. III. Effect of iron overload and hexachlorobenzene on liver haem biosynthesis. Br. J. Haematol. 23 : 587-593.

26. Dehlin, O., L. Enerbäck, and O. Lundvall. 1973. Porphyria cutanea tarda-A genetic disease? A biochemical and fluorescence microscopial study in four families. Acta Med. Scand. 194: 265-270. 